\title{
Juvenile Bullous Pemphigoid - a Case Report
}

\author{
Kristina KOSTIĆ ${ }^{1}$, Lidija KANDOLF SEKULOVIĆ ${ }^{*}$, Radoš D. ZEČEVIĆ \\ ${ }^{1}$ Department of Dermatovenereology, Military Medical Academy, Belgrade \\ ${ }^{2}$ Department of Dermatovenereology, Faculty of Medicine, Military Medical Academy, University of Defence, Belgrade \\ ${ }^{*}$ Correspondence: Lidija KANDOLF SEKULOVIĆ, E-mail: lkandolfsekulovic@gmail.com \\ UDC 616.527-08-053.2

\begin{abstract}
Bullous pemphigoid is an autoimmune blistering disease that predominantly affects elderly persons and rarely children. We present a 12-year-old girl with sudden appearance of tense blisters on an erythematous base on the trunk, neck, hands and legs with intense pruritus. Standard laboratory test results were within the normal range except for blood eosinophilia of $12 \%$ of the total white cell count. Skin biopsy specimens showed evolving subepidermal blisters with perivascular lymphohistiocytic, eosinophil and neutrophil infiltrations in the papillary dermis. Direct immunofluorescence of perilesional skin showed linear, continuous deposits of IgG and C3 along the dermoepidermal junction. Indirect immunofluorescence showed circulating anti-basement membrane zone IgG autoantibodies at a titer of 1:80. We started treatment with systemic corticosteroids, methylprednisolone $0,5 \mathrm{mg} / \mathrm{kg}$ per day and $500 \mathrm{mg}$ erythromycin 4 times a day during 10 days. After 3 days 50 mg dapsone (DDS, 4,4-diaminodiphenylsulphone) per day was added. After a few days, there were no new changes on the skin and pruritus disappeared completely.
\end{abstract}

\section{Key words}

Pemphigoid, Bullous; Autoimmune Diseases; Child; Pruritus; Fluorescent Antibody Technique, Indirect; Dapsone; Treatment Outcome

$\mathrm{B}$ ullous pemphigoid (BP) is an autoimmune blistering disease that predominantly affects elderly persons and rarely children. It is an immunemediated disease that is associated with a humoral and cellular response directed against the two wellcharacterized self-antigens: bullous pemphigoid antigen 1 (BPAG1) and bullous pemphigoid antigen 2 (BPAG2), both components of hemidesmosome junctional adhesion complex in the skin and mucosa. The cutaneous manifestations of BP may be extremely polymorphic. In the non-bullous phase of the disease, signs and symptoms are frequently non-specific, from mild to severe intractable pruritus. The bullous stage of $\mathrm{BP}$ is characterized by the development of vesicles and bullae on apparently normal or erythematous $\operatorname{skin}(1)$.

The first well-documented report of childhood $\mathrm{BP}$ was published in 1970 (2). The diagnostic criteria are the same as in adults: appearance of tense bullae, histopathological findings of subepidermal blisters with eosinophilia, direct immunofluorescence (DIF) showing linear deposition of IgG or C3 as the major immunoreactants at the basement membrane zone and presence of circulating $\operatorname{IgG}$ anti-basement membrane zone autoantibodies (3). The course of childhood BP is usually indolent with rare relapses (4). Even so, the disease may be life threatening, particularly if appropriate management is delayed (5).

\section{Case report}

We present a 12-year-old girl, with sudden appearance of tense blisters on an erythematous base on the trunk, neck, hands and legs (Figure 1,2) with intense pruritus. Mucous membranes were not involved. The family history showed no evidence of autoimmune diseases. Standard laboratory test results were within the normal range except for blood eosinophilia of $12 \%$ of the total white cell count. Histopathological analysis of lesional and perilesional skin samples revealed subepidermal blisters with perivascular 


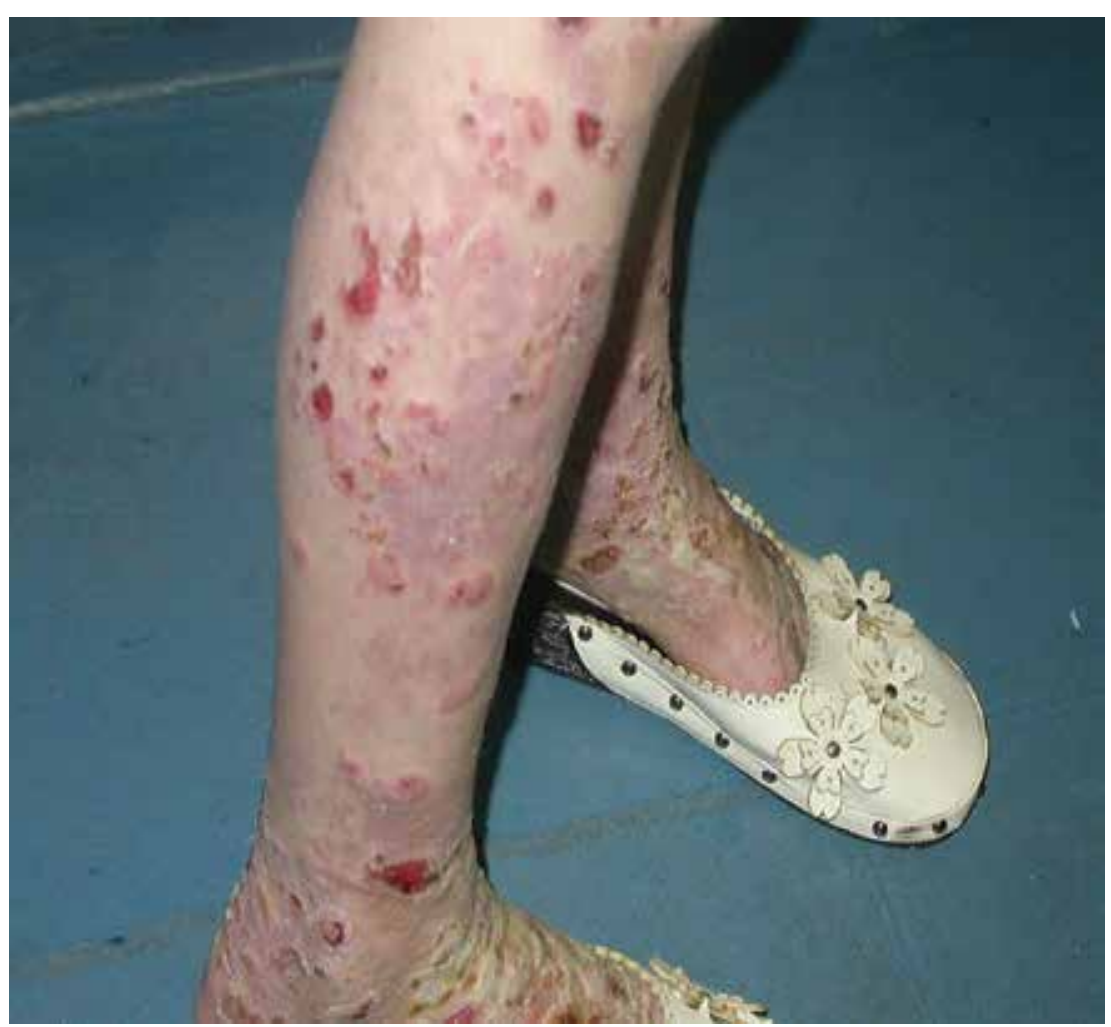

Figure 1. Tense blisters on an erythematous base on the legs

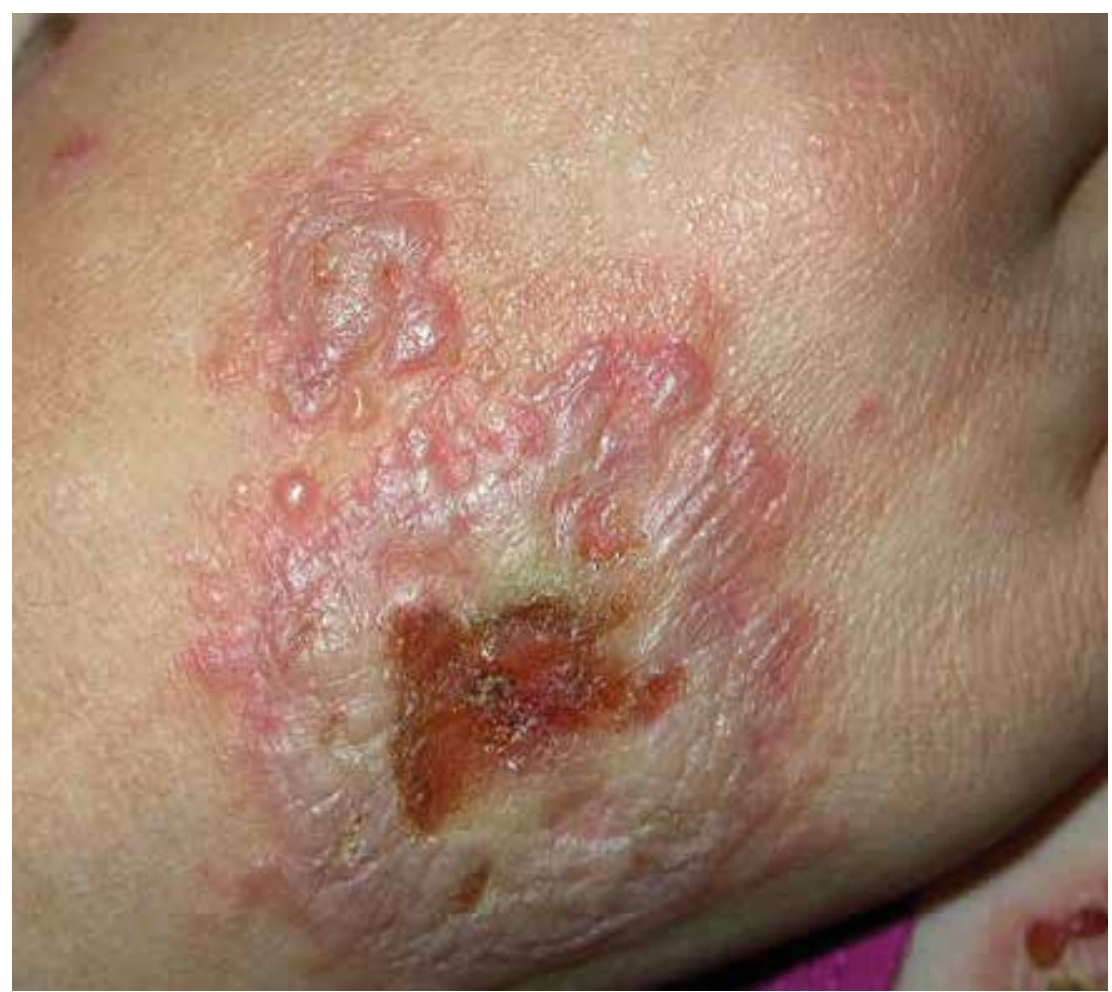

Figure 2. Annular distribution of blisters, typical for juvenile bullous pemphigoid 
lymphohistiocytic, eosinophil and neutrophil infiltrations in the papillary dermis (Figure 3). Direct immunofluorescence (DIF) test of perilesional skin demonstrated linear, continuous deposits of IgG and $\mathrm{C} 3$ along the dermoepidermal junction (Figure 4). Indirect immunofluorescence (IIF) microscopy demonstrated circulating anti-basement membrane zone IgG autoantibodies at a titer of 1:80.

The diagnosis of juvenile bullous pemphigoid was established based on clinical manifestations (tense bullae on an erythematous base, pruritus), characteristic histopathological findings (subepidermal splits with dominant eosinophils in the cavity and in dermal infiltrations), direct immunofluorescence (DIF) microscopy (linear IgG and C3 deposits along the basement membrane zone) and positive IIF test $1: 80$.

Treatment with systemic corticosteroids, methylprednisolone $0,5 \mathrm{mg} / \mathrm{kg}$ per day and $500 \mathrm{mg}$ erythromycin 4 times per day was initiated. However, after 3 days the disease was not under control, so 50 $\mathrm{mg}$ dapsone (DDS, 4,4-diaminodiphenylsulphone) per day was added. After a few days, there were no new changes on the skin and pruritus disappeared completely and the therapy with methylprednisolone and dapsone was not discontinued after discharge. The therapy was well tollrated tollerated. Hypertension was not recorded during therapy, while laboratory findings, including glucose as well as arterial blood pressure, were within reference values. Two months later, the disease was in complete remission. During a 6 months follow up, methylprednisolone was tapered to $4 \mathrm{mg}$ per week, until the daily dose of $4 \mathrm{mg}$ was achieved in combination with $50 \mathrm{mg}$ dapsone per day.

\section{Discussion}

Autoimmune bullous diseases with subepidermal split are very rare in children. The first case of juvenile bullous pemphigoid (JBP) was published in 1970 (1). In 1993, Fisler and al. analyzed 53 collected cases of juvenile bullous pemphigoid, where the age of onset ranged from 2.5 months to 14 years (4). Female patients accounted for $60 \%$ of cases.

The disease most often occurs in children older than 8 years. None of the children had any form of malignancy or any other associated disease (3). We presented a 12 year-old girl, with no evidence of other acute or chronic disease. Sudden appearance of bullous

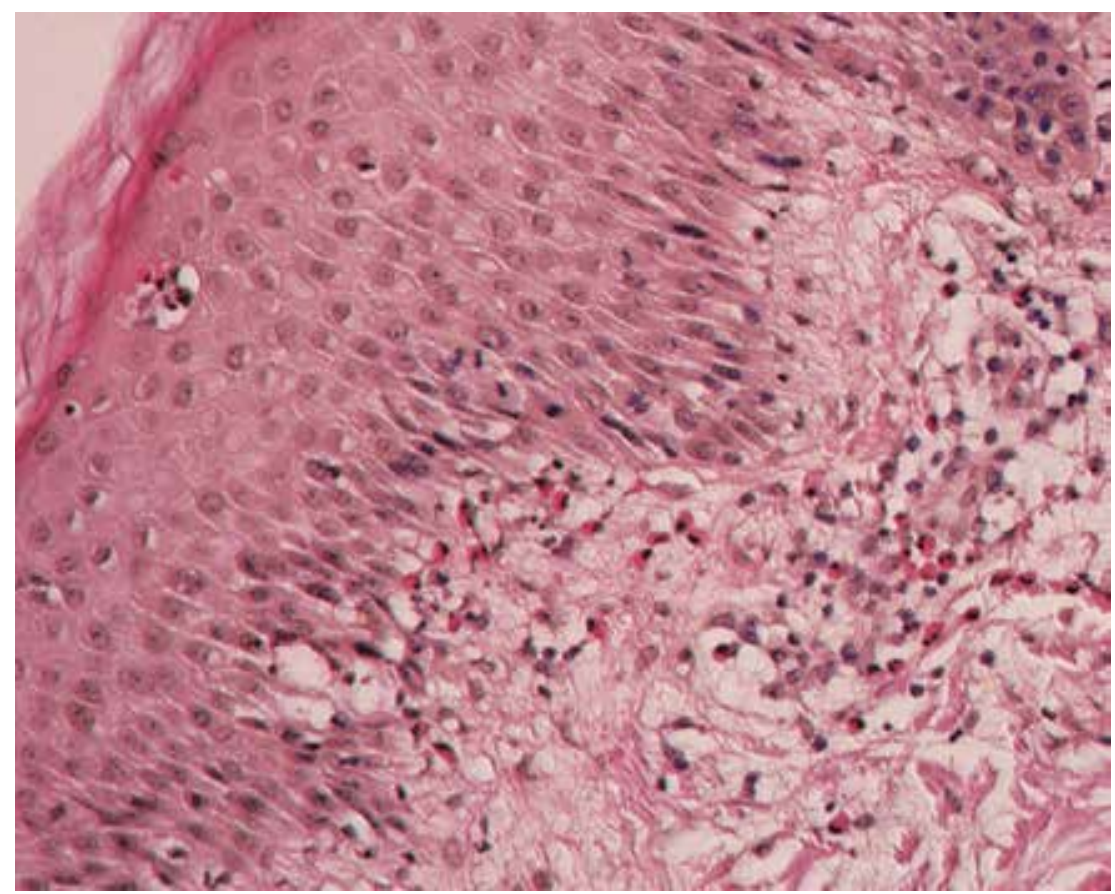

Figure 3. Histopathological analysis of lesional and perilesional skin samples reveales subepidermal blisters with eosinophilic spongiosis and perivascular lymphohistiocytic, eosinophil and neutrophil infiltrations in the papillary dermis (HE, $\mathrm{x} 400)$ 


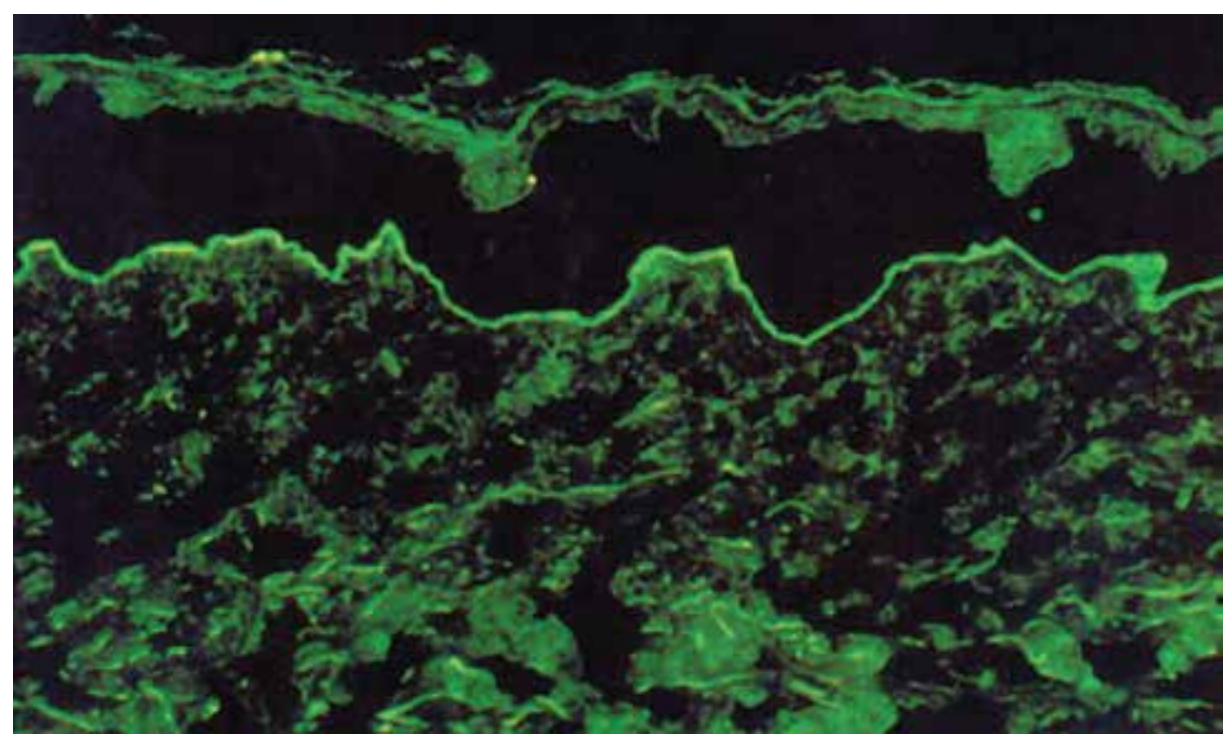

Figure 4. Direct immunofluorescence test of perilesional skin demonstrates linear, continuous deposits of IgG and $\mathrm{C} 3$ along the dermoepidermal junction

eruptions was not accompanied by deterioration of the general condition. Skin eruption was generalized, but there was no involvement of mucous membranes. In case series from the Pediatric Dermatology Unit, University Clinic of Dermatology, Belgrade, three of six children with BP had changes on the oral mucosa (6).

In our case, histopathology and DIF analyses were characteristic of BP: subepidermal blistering with perivascular lymphohistiocytic, eosinophil and neutrophil infiltrations in the papillary dermis, while DIF showed linear, continuous deposits of IgG and C3 along the dermoepidermal junction. In a study including six cases with JBP, three showed deposits of IgG, C3 and IgA (6). We did not find deposits of IgA in the perilesional skin. About $60-80 \%$ of patients present with circulating antibasement membrane IgG autoantibodies, and there is no difference between adults and children considering that matter.

Bullous pemphigoid may coexist with lichen planus in both adults and children (7). Immunopathologically, the disease is identical to bullous pemphigoid. However, it is usually possible to differentiate bullous pemphigoid from lichen planus pemphigoides on clinical base alone: in bullous pemphigoid there is no evidence of associated lichen planus (8). In our case, positive direct DIF test helped to exclude bullous lichen planus (9).

Systemic corticosteroids are the best choice for the initial treatment of JBP. In children, as in adults, a minimal dose of drugs that controls the disease is recommended $(2,10)$. Powell et al. analyzed immunobullous disease in children and its good response to sulfa drugs and macrolides (11). Macrolide antibiotics, including erythromycin, have antiinflammatory effects similar to those of tetracyclines. It has been shown that they exhibit not only a steroidsparing effect when used in conjunction with steroids, but also an inhibition of neutrophil chemotaxis (11). All patients responded well to the therapy with dapsone, sulphonamides and systemic erythromycin (11). In our patient, we initiated therapy with a systemic corticosteroid methylprednisolone $0,5 \mathrm{mg} /$ kg daily and oral $500 \mathrm{mg}$ erythromycin 4 times a day. After 3 days the disease was still not under control, so we added dapsone $50 \mathrm{mg}$ per day. Prompt therapeutic effect with reduction of pruritus was obtained, and there were no new blisters. Spontaneous remission of JBP may be achieved within 5 years and it has a good prognosis, although in some children the course is less benign. The average time to achieve control of BP was about 1 month in the study of Gajić-Veljić et al. (6), which was shorther than in the study reported by Weston et al. (12), where remission with systemic corticosteroids and dapsone was achieved after 2 
months. Complete remission was achieved in all JBP patients in both studies, as well as in our patient.

\section{Conclusion}

In general, children with BP have a good prognosis. Remission is achieved within several weeks to a few months. In most children the response to treatment is rather fast and ranges between a few days to several months, as in our patient. In juvenile bullous pemphigoid relapses are very rare, which is opposite to much slower remission and higher rate of relapses reported in adults suffering from BP.

\section{Abbreviations}

BP - Bullous pemphigoid

BPAG1 - Bullous pemphigoid antigen 1

BPAG2 - Bullous pemphigoid antigen 2

IgG - Immunoglobulin G

C3 - Complement component C3

DIF - Direct immunofluorescence

IIF - Indirect immunofluorescence

JBP - Juvenile bullous pemphigoid

\section{References:}

1. Nemeth AJ, Klein AD, Gould EV, Schachner LA. Childhood bullous pemphigoid: clinical and immunologic features, treatment and prognosis. Arch Dermatol 1991;127:378-86.

2. Borradori L, Bernard P. Pemphigoid group. In: Bolognia JL,
Jorizzo JL, Rapini RP. Dermatology. London: Mosby Elsevier; 2008. p. 431-45.

3. Waisbourd-Zinman O, Ben-Amitai D, Cohen AD, Feinmesser M, Mimouni D, Adir-Shani A, et al. Bullous pemphigoid in infancy: Clinical and epidemiologic characteristics. J Am Acad Dermatol 2008;58(1):41-8.

4. Fisler RE, Saeb M, Liang MG, Howard RM, McKee PH. Childhood bullous pemphigoid: a clinicopathologic study and review of the literature. Am J Dermatopathol 2003;25:183-9.

5. Chiaverini C, Hamel-Teillac D, Gilbert D, Prost Y. Absence of anti-BP180 antibodies in mothers of infants with bullous pemphigoid. Br J Dermatol 2006;154:839-43.

6. Gajić-Veljić M, Nikolić M, Medenica L. Juvenile bullous pemphigoid: the presentation and follow-up of six cases. J Eur Acad Dermatol 2010;24:69-72.

7. Wojnarowska F, Venning VA. Immunobullous diseases. In: Burns T, Breathnach S, Cox N, Griffiths C, editors. Rook's textbook of dermatology. $6^{\text {th }}$ ed. Oxford: Blackwell Publishing Ltd; 2010. p. 40.1-62.

8. Breathnach SM. Lichen planus and lichenoid disorders. In: Burns T, Breathnach S, Cox N, Griffiths C, editors. Rook's textbook of dermatology. $6^{\text {th }}$ ed. Oxford: Blackwell Publishing Ltd; 2010. p. 41.1-28.

9. Arsov B, Popadić S, Nikolić M. Bullous lichen planus in childhood. Serb J Dermatol Venereol 2011;3(1):28-32.

10. Voltan E, Maeda JY, Muniz Silva MA, Maruta CW, Santi CG, de Almeida Zimbres S, et al. Childhood bullous pemphigoid: report of three cases. J Dermatol 2005;32:387-92.

11. Powel J, Kirtschig G, Allen J, Dean D, Wojnarowska F. Mixed immunobullous disease of childhood: a good response to antimicrobials. Br J Dermatol 2001;144:769-74.

12. Weston WL, Morelli JG, Huff JC. Misdiagnosis, treatments, and outcomes in the immunobullous diseases in children. Pediatr Dermatol 1997;14:264-72.

\section{Juvenilni bulozni pemfigoid - prikaz slučaja}

\section{Sažetak}

Uvod. Bulozni pemfigoid je autoimuna bulozna dermatoza koja se najčešće javlja kod pacijenata starijeg životnog doba; retko se javlja kod dece.

Prikaz slučaja. Prikazujemo slučaj devojčice, uzrasta 12 godina, sa iznenadnom pojavom napetih bula na eritematoznoj koži trupa, vrata, gornjih i donjih ekstremiteta uz intenzivan pruritus. Učinjene su standardne laboratorijske analize. Svi nalazi su bili u redu osimutvrđeneeozinofilije u perifernojkrvikojajeiznosila $12 \%$ od ukupnog broja leukocita. Histopatološki nalaz bioptirane kože pokazao je subepidermalni rascep sa perivaskularnim infiltratom, dominantno eozinofilnim i neutrofilnim, u papilarnom dermu. Direktnom imunofluorescentnom mikroskopijom perilezione kože viđeni su linearni, kontinuirani depoziti $\operatorname{IgG}$ i C3 antitela duž zone bazalne membrane. Indirektnom imunofluorescentnom mikroskopijom detektovana su cirkulišuća IgG autoantitela prema komponenti zone bazalne membrane u titru $1: 80$. Započeta je terapija sistemskim kortikosteroidima, metilprednizolon 0,5 $\mathrm{mg} / \mathrm{kg}$ dnevno i eritromicinom per os u dozi od $500 \mathrm{mg}$ 4 puta dnevno, a nakon tri dana u terapiju je uključen i dapson (DDS, 4,4-diamino-difenil sulphone) u dozi $50 \mathrm{mg}$ dnevno. Nekoliko dana po započetoj terapiji pruritus se povukao, a nove promene na koži se nisu pojavljivale.

Diskusija. Ukoliko se javi u dečjem uzrastu, bulozni pemfigoid najčešće pogađa decu stariju od 8 godina. 
Opšte stanje je obično nepromenjeno, a ni kod jednog deteta do sada nije utvrđen prateći malignitet. Promene mogu da zahvate i vidljive sluzniice, opisani su slučajevi sa promenama na orofaringealnoj sluznici. Presudni dijagnostički značaj ima patohistološki nalaz i direktna imunofluorescencija kojom se duž zone bazalne membrane dokazuje prisustvo kontinuiranih linearnih depozita sastavljenih iz IgG i C3 antitela. Opisani su depoziti sastavljeni i od IgA. Kao i kod odraslih, u 60-80\% slučajeva indirektnom imunofluorescencijom potvrđuje se prisustvo $u$ serumu cirkulišućih IgG antitela usmerenih protiv bazalne membrane, koji su bili prisutni i kod našeg pacijenta.

\section{Ključne reči}

Bulozni pemfigoid; Autoimune bolesti; Dete; Pruritus; Indirektna imunofluorescentna metoda; Dapson; Ishod lečenja 